Instructions/Template for Preparing Manuscript for Jendela Nursing Journal

\title{
Self-Concept Related to Stress in PLWHA
}

\author{
Jek Amidos Pardede ${ }^{1}$, Cut Inten Balqis ${ }^{1}$, Galvani Volta Simanjuntak ${ }^{1}$ \\ Program Studi Ners, Universitas Sari Mutiara Indonesia \\ Corresponding author:jekpardedemi@rocketmail.com
}

\begin{abstract}
Background: HIV / AIDS is an infectious disease that is very dangerous and deadly. So that the self-concept of HIV / AIDS patients sees themselves negatively and causes stress.

Purpose: This study aims to determine the relationship between self-concept and stress in PLWHA.

Methods: The design of this research is correlation analytic with a cross-sectional approach. The population of this study was all HIV / AIDS patients who were in Posyansus at RSUP H. Adam Malik Medan. The sampling technique was purposive sampling technique and obtained 39 patients. The data collection tool used a questionnaire that had been tested for validity and reliability, for the self-concept questionnaire as many as 15 statements with a value of $r=0.903$ with a Cronbach's Alpha value of 0.914 and stress using the DASS 42 questionnaire consisting of 42 statements with a value of $r=0.916$ with a Cronbach's Alpha value of 0.948 . The test used for data analysis was the Chi-Square test with a p-value $<0.05$.
\end{abstract}

Results: The results showed that the majority of self-concept was positive (92.2\%) and the majority of stress was mild $(51.3 \%)$ and the p-value $=0.029<0.05$.

Conclusion: In conclusion, there is a significant relationship between self-concept and stress in PLWHA.

\section{Keywords:}

PLWHA, Self-Concept, Stress

\section{LATAR BELAKANG}

AIDS yang disebabkan oleh virus Human Immunodeficiency Virus (HIV) adalah epidemik penyakit menular di dunia yang dianggap sebagai masalah kesehatan masyarakat terbesar dalam beberapa tahun terakhir, AIDS muncul sebagai ancaman terbesar bagi kehidupan manusia. Kasus AIDS yang paling banyak di dunia yaitu Afrika Selatan, Amerika, Nigeria, India, Zimbabwe, Rusia, dan Indonesia (Gyar, Reuben \& Haruna, 2014). Negara peringkat pertama yang memiliki penduduk yang positive HIV/AIDS adalah Region Sub Sahara, dan pada peringkat kedua diduduki oleh Asia yang memiliki jumlah kasus sebanyak 36.9 juta (UNAIDS, 2017). Menurut WHO (2020), Diperkirakan ada 38,0 juta orang yang hidup dengan HIV pada akhir 2019.

Kasus HIV/AIDS di Indonesia pada tahun 2017 sebanyak 330.152 orang, dengan terinfeksi HIV sebanyak 242.699 orang dan yang mengalami AIDS sebanyak 87.453 
orang. Urutan prevalensi HIV/AIDS di provinsi yang ada di Indonesia antara lain, yang tertinggi Jawa Timur, dan di ikuti Jawa Barat, DKI Jakarta, Jawa Tengah, Papua, Bali, Sumatera Utara dan paling rendah Sulawesi Barat (Kemenkes RI, 2017). Hasil Riskesdas (2018) di 32 Provinsi di Indonesia tentang Pengetahuan HIV/AIDS menunjukkan dari 21 pertanyaan, $4 \%$ mampu menjawab dengan benar 16-24 pertanyaan, 2\% tidak tahu tentang penyakit HIV/AIDS, 31,8 \% mampu menjawab 8-15 pertanyaan dan $65,2 \%$ mampu menjawab 1-7 pertanyaan dengan benar.

Laporan dinas kesehatan Provinsi Sumatera Utara, ditemukan 2.593 kasus penderita HIV(+) dan 4.125 kasus penderita AIDS. Jumlah pasien AIDS yang dilaporkan meninggal adalah 705 orang golongan kelompok umur HIV(+) tertinggi umur 20-29 tahun, jumlah kumulatif AIDS tertinggi pada umur 30-39 tahun. Penderita HIV/AIDS tertinggi menurut kabupaten/kota adalah Kota Medan yaitu 3.790 kasus (Dinkes Provsu, 2015). Infeksi HIV saat ini belum ditemukan pengobatannya, sehingga sangat memungkinkan seseorang yang menderita AIDS sering mengalami masalah-masalah psikologis terutama gangguan konsep diri, kecemasan, depresi, rasa bersalah akibat perilaku seks dan penyalahgunaan obat, marah dan stres serta timbulnya dorongan untuk bunuh diri. Reaksi spontan masyarakat pada saat pertama kali menghadapi penyakit AIDS ini adalah menjauhkan diri dari penderita, berusaha tidak menyentuh penderita (Hutapea, 2011; Laras \& Prasetyo, 2017)

Orang dengan HIV/AIDS (ODHA) memiliki permasalahan pada aspek psikologis dan sosial dan spiritual yang akan menimbulkan permasalahan yang kompleks yang dapat mempengaruhi perjalanan penyakit dan kondisi fisik ODHA. Dampak HIV/AIDS pada aspek social dan spiritual seperti stigma, diskriminasi, kehilangan iman pada ODHA, dan akan menambah beban bagi aspek psikologis ODHA itu sendiri (Pardede, Simanjuntak \& Waruwu, 2020). Pasien HIV/AIDS mengalami perubahan secara psikologis, terkait dengan konsep dirinya. Perubahan ini berdampak kepada konsep diri karena mereka menganggap bahwa dirinya lemah tidak berdaya. Sedangkan konsep diri pada penderita HIV/AIDS secara keseluruhan berada pada kategori kurang atau bahkan sangat kurang. Salah satu penyebab kurangnya konsep diri ini adalah sikap negatif dari masyarakat. Penderita HIV umumnya telah mencoba untuk memperbaiki diri dengan bersikap baik di lingkungan masyarakat, namun sikap dan pandangan negatif dari masyarakat seakan menyudutkan mereka sehingga sangat mempengaruhi konsep diri mereka (Sarikusuma \& Hasanah, 2012). Kondisi kesehatan yang semakin menurun ditambah dengan faktor penolakan dari lingkungan atau stigma dari masyarakat yang menambah gangguan psikologis ODHA seperti stres.

Stres merupakan suatu keadaan ketika individu merespon perubahan dalam status keseimbangan normal (Berman, Snyder, \& Frandsen, 2015). Stres pada ODHA juga dikaitkan dengan perasaan bahwa kesehatannya buruk, rasa sakit kronis dan kehilangan daya ingat serta konsentrasi, Lamanya suasana hati yang lesu, kegelisahan atau kemarahan mungkin biasanya menjadi bagian dari penyesuaian terhadap penyakit. Stres terhadap pasien AIDS akan menuntut ODHA untuk memiliki keterampilan mengolah stres akibat dampak yang di timbulkan saat ODHA menyandang statusnya. Untuk mengurangi dapak dari stressor yang mengancam kualitas hidup ODHA, mereka menggunakan koping stress. Koping stres merupakan cara yang dilakukan untuk 
mengatasi situasi atau problem yang dianggap sebagai tantangan, ketidak adilan atau merugikan sebagai ancaman (Deekshitulu, 2015). Koping stress dimaksud adalah menggunakan konsep diri yang positif sehingga tres ODHA akan hilang.

Berdasarkan survei awal yang dilakukan peneliti didapatkan bahwa data jumlah pasien HIV/AIDS yang dirawat inap pada tahun 2016 yaitu sejumlah 524 pasien, Hasil wawancara peneliti kepada 10 pasien yang dirawat inap, dari 10 pasien di temukan 6 diantaranya mengatakan kurangnya rasa percaya diri dan konsep dirinya terganggu ketika melihat atau berhubungan dengan orang lain dan 4 pasien mengatakan malu keluar rumah sehingga aktivitas yang harus dilakukan jadi terganggu karena takut orang lain akan mengejek dan mempermalukan dirinya. Berdasarkan fenomena yang sudah diuraikan, maka peneliti tertarik menliti tentang konsep diri dengan stress pasien HIV/AIDS untuk meningkatkan konsep diri pasien sehingga tidak menimbulkan stres sehingga pasien mampu bertahan hidup.

\section{TUJUAN}

Untuk mengetahui hubungan konsep diri dengan stres pasien HIV/AIDS.

\section{METODE}

Desain penelitian ini adalah analitik kolerasi dengan pendekatan cross sectional yaitu suatu penelitian yang mempelajari dinamika hubungan konsep diri dengan stress pasien HIV/AIDS, dengan cara pendekatan, obeservasi atau pengumpulan data. Populasi dalam penelitian ini adalah seluruh pasien HIV/AIDS yang di Rawat Jalan di RSUP H. Adam Malik Medan sejumlah 524 Pasien. Jumlah sampel dalam penelitian ini adalah 39 pasien yang dirawat jalan. Teknik Sampel dalam penelitian ini adalah Purposive Sampling yaitu pengambilan sampel berdasarkan kriteria yang ditentukan oleh peneliti yang dapat dianggap mewakili karakteristik populasinya.

Alat pengumpulan data menggunakan kuesioner, Kuesioner konsep diri dengan 15 pernyataan sudah di uji validitas dan reabilitas dengan nilai $r$ tabel 0,903 dengan nilai Cronbach's Alpha 0,914. Kuesioner Depression Anxiety and Strees Scale 42 (DASS 42) yang sudah diuji validitas dan reabilitas oleh Lovinbond \& Lavinbond (1995). Kuesioner terdiri dari 42 pernyataan dengan nilai $r$ 0,916 dengan nilai Cronbach's Alpha 0,9483. Teknik analisis yang di gunakan dalam penelitian ini adalah uji Chi Square dengan nilai p value $<0,05$.

\section{HASIL}

Hasil penelitian tentang data demografi responden $(n=39)$ menunjukkan bahwa usia responden mayoritas usia 20-29 tahun (61,5\%), jenis kelamin respoden mayoritas perempuan $(61,5 \%)$.

Tabel 1. Konsep Diri Pasien HIV/AIDS ( $\mathrm{n}=39)$

\begin{tabular}{ccc}
\hline Konsep Diri & $\mathrm{n}$ & $\%$ \\
\hline Positif & 36 & 93,1 \\
Negatif & 3 & 6,9 \\
\hline
\end{tabular}


Berdasarkan Tabel 1, dapat dilihat mayoritas konsep diri responden adalah positif sebanyak 36 orang $(93,1 \%)$.

Tabel 2. Stres Pasien HIV/AIDS

\begin{tabular}{lcc}
\hline \multicolumn{1}{c}{ Stres } & $\mathrm{n}$ & $\%$ \\
\hline Ringan & 20 & 51,3 \\
Sedang & 17 & 43,6 \\
Berat & 2 & 51 \\
\hline
\end{tabular}

Berdasarkan Tabel 2, dapat dilihat bahwa mayoritas responden memiliki stres ringan sebanyak 20 responden $(51,3 \%)$.

Tabel 3. Hubungan Konsep Diri dengan Stres Pasien HIV/AIDS

\begin{tabular}{lccccccccc}
\hline \multirow{2}{*}{$\begin{array}{l}\text { Konsep } \\
\text { Diri }\end{array}$} & \multicolumn{9}{c}{ Stres } \\
& \multicolumn{2}{c}{ Ringan } & \multicolumn{2}{c}{ Sedang } & \multicolumn{2}{c}{ Berat } & \multicolumn{2}{c}{ Total } & \multirow{2}{*}{$p$} \\
\cline { 2 - 7 } & $\mathrm{n}$ & $\%$ & $\mathrm{n}$ & $\%$ & $\mathrm{n}$ & $\%$ & $\mathrm{n}$ & $\%$ & \\
\hline Positif & 20 & 51,3 & 15 & 38,5 & 1 & 2.6 & 36 & 92.3 & 0.029 \\
Negatif & 0 & 0 & 2 & 5,1 & 1 & 2,6 & 3 & 7,7 & \\
Total & 20 & 51,3 & 17 & 43,6 & 2 & 5,1 & 39 & 100 & \\
\hline
\end{tabular}

Berdasarkan Tabel 3, dapat dilihat bahwa mayoritas konsep diri positif dengan minoritas stres ringan sebanyak 20 orang $(51,3 \%)$, minoritas stres sedang sebanyak 15 orang $(38,5 \%)$, mioritast stres berat sebanyak 1 responden $(2,6 \%)$, Konsep diri negatif dengan minoritas stres ringan sebanyak 0 responden $(0 \%)$, minoritas stres sedang sebanyak 2 responden $(5,1 \%)$ dan minoritas stres berat sebanyak 1 responden $(2,6 \%)$. Dari hasil uji statistik menunjukkan bahwa nilai $\mathrm{p}=0,029$ yang artinya ada hubungan yang signifikan antara konsep diri dengan stres pasien HIV/AIDS.

\section{PEMBAHASAN}

Konsep Diri Pasien HIV/AIDS

Hasil penelitian menunjukkan bahwa konsep diri responden mayoritas negatif sebanyak 6,9\%. Hal ini diperoleh dari hasil jawaban responden dari kuesioner konsep diri dengan 15 pernyataan. Konsep diri negatif karena sebagian distribusi jawaban dari responden bersikap pesimik terhadap keadaan yang dialaminya, tidak mampu menghargai dirinya, menutup diri, membenci dirinya dan malu berinteraksi dengan orang lain. Selain itu, jawaban responden kurang percaya diri dengan penampilannya, merasa malu jika kondisi tubuhnya semakin kurus sehingga membuat malu saat berinteraksi dengan orang lain, sering menyalahkan diri sendiri dan merasa dirinya tak berguna lagi. Hasil penelitian Wahyu, Taufik, \& Ilyas (2012). Konsep diri ODHA secara keseluruhan menyangkut aspek fisik, etika dan moral, diri pribadi (personal self), diri keluarga (family self) dan sosial berada pada kategori kurang dan kurang sekali. Perubahan 
penampilan fisik ODHA karena HIV/AIDS tidak mempengaruhi pergaulan ataupun membuat mereka merasa minder, akan tetapi keterbukaan tentang status mereka pada keluarga dan teman dekat membutuhkan dukungan dari Kelompok dukungan sebaya (Rusmawati, 2012)

Perasaan rendah diri yang muncul akibat dari perubahan fisik yang dialami ODHA membuat pengidap HIV/AIDS menarik diri dari lingkungan tempat tinggalnya. Penderita HIV/AIDS kebanyakan hanya merasa bebas mengekspresikan diri mereka dalam komunitas ODHA (Novianti, Istiyanto, \& Adi, 2020). Bersbeda dengan hasil penelitian Pardede, Hutajulu \& Pasaribu (2020) bahwa Harga diri pasien HIV/AIDS di RSUP H. Adam Malik mayoritas tinggi, karena Orang dengan harga diri yang tinggi cenderung bersikap positif terhadappermasalahan yang dihadapinya, sebaliknya orang yang dengan harga diri rendah akan menghadapi suatu masalah secara emosional, tergesa-gesa, dan kadang tidak memikirkan dampak di masa yang datang (Ardani \& Handayani, 2017). Konsep diri merupakan semua ide, pikiran, kepercayaan dan pendirian yang diketahui individu tentang dirinya dan mempengaruhi individu dalam berhubungan dengan orang lain. Hal ini termasuk persepsi individu akan sifat dan kemampuannya, interaksi dengan orang lain dan lingkungan, nilai-nilai yang berkaitan dengan pengalaman dan objek, tujuan serta keinginannya (Stuart, 2014).

Menurut asumsi peneliti bahwa pasien cenderung bersikap pesimik terhadap keadaan yang dialaminya, tidak mampu menghargai dirinya, menutup diri, membenci dirinya dan malu berinteraksi dengan orang lain, seharusnya pasien lebih membuka diri sehingga mampu berinteraksi dengan orang lain dengan baik dan kemungkinan besar akan membantu dalam proses penyembuhan karena orang lain akan memberikan solusi dalam penyembuhan pasien HIV/AIDS.

\section{Stres Pasien HIV/AIDS}

Hasil penelitan bahwa stres responden mayoritas ringan sebanyak 51,3\%. Hal ini diperoleh dari hasil jawaban 20 responden. Responden sering merasa dirinya mudah kesal, merasa dirinya sedih dan tertekan, merasa takut, gelisah, merasa bahwa hidup tak berarti, takut tanpa alasan yang jelas, putus asa mudah tersinggung, tidak berharga sebagai seorang manusia. Hasil penelitian Sari \& Wardani (2017). Menunjukkan bahwa tingkat stress pasien HIV/AIDS mayoritas berat 80,52\%. Hidayanti (2013). Menyatakan HIV/AIDS merupakan ketegori penyakit yang menyebabkan stress tingkat tinggi bagi penderitanya. Stress tersebut disebabkan karena perubahan fisik yang cukup signifikan dan dampak psikososial penyakit (stigma dan diskriminasi) yang harus mereka terima dari masyarakat.

Stres merupkan respon fisiologis untuk stressor, ketika tubuh bereaksi terhadap tantangan. Stres biasanya menggambarkan suatu kondisi negatif atau kondisi positif yang dapat berdampak pada mental dan fisik kesejahteraan seseorang. Jangka panjang atau stres kronis melemahkan sistem kekebalan tubuh dan menyebabkan kerentanan penyakit dan membuat tubuh rentan terhadap depresi. gangguan kejiwaan yang paling umum pada pasien AIDS adalah depresi. (Deekshitulu, 2015). Seseorang yang merasakan ketidakseimbangan antara tuntutan yang dihadapi dengan kemampuan untuk mengatasi tuntutan tersebut bahwa stres terjadi ketidakseimbangan antara tuntunan lingkungan kemampuan individu untuk melakukan respon adekuat terhadap tuntutan. 
Menurut asumsi peneliti bahwa pasien yang cenderung merasa dirinya mudah kesal, merasa dirinya sedih dan tertekan, tidak berharga sebagai seorang manusia, merasa takut dan mudah tersinggung akan lebih mudah stress. Sehingga pasien HIV/AIDS perlu diberikan dukungan agar mampu mengatasi stress yang dialaminya selama sakit.

Konsep diri dengan stres Pasien HIV/AIDS

Hasil penlitian menunjukkan bahwa nilai $\mathrm{p}=0,029<0,05$, yang artinya ada hubungan yang signifikan antara konsep diri dengan stres pasien HIV/AIDS. Pasien HIV/AIDS (ODHA) mengalami stress karena label negative dari masyarakat. Hasil penelitian Sarikusuma \& Hasanah (2012). Dampak dari label negatif dan diskriminasi yang diterima partisipan mempengaruhi penentuan konsep diri partisipan yang meliputi perilaku, pemikiran, perasaan dan kebiasaan. Partisipan menjadi seseorang yang pendiam, tidak mau bersosialisasi atau menarik diri dari lingkungan, selalu berpikiran negatif, merasa bahwa dirinya paling buruk, mudah putus asa dan selalu muncul keinginan untuk mati.

Asumsi peneliti bahwa konsep diri pada orang dengan HIV/AIDS cenderung memiliki konsep diri negatif dimana orang dengan HIV/AIDS meyakini dan memandang bahwa dirinya lemah, tidak berdaya, tidak dapat berbuat apa-apa, tidak kompeten, tidak menarik, tidak disukai dan kehilangan daya tarik terhadap hidup. Mereka cenderung bersikap pesimis terhadap kehidupan dan kesempatan yang dihapainya. Tetapi konsep diri yang positif memiliki konsep diri tingkat stres yang rendah bila dibandingkan dengan individu dengan konsep diri negative disebabkan karena konsep diri yang memiliki akan mempengaruhi individu dalam proses berfikir, bersikap dan bertingkah laku.

\section{SIMPULAN}

Hasil penelitian dapat disimpulkan bahwa pasien HIV/AIDS memiliki konsep diri mayoritas positif, stres pasien mayoritas ringan dan ada hubungan signifikan antara Konsep Diri dengan Stres Pasien HIV/AIDS dengan nilai p value $=0,029$.

\section{REFERENSI}

Ardani, I., \& Handayani, S. (2017). Stigma terhadap orang dengan HIV/AIDS (ODHA) sebagai hambatan pencarian pengobatan: Studi Kasus pada Pecandu Narkoba Suntik di Jakarta. Indonesian Bulletin of Health Research, 45(2), 81-88. doi : 10.22435/bpk.v45i2.6042.81-88

Berman, A.T., Snyder, S., \& Frandsen, G. (2015). Kozier \& Erb's fundamentals of nursing: Concept, process and practice (10th Ed.).Cambridge: Pearson Publisher UK

Deekshitulu, B. (2015). Stress aspects in HIV/AIDS Disease. International Journal of Indian Psychology, Vol.3 (1), doi: 10.25215/0301.510, DIP: 18.01.510/20150301

Gyar, S. D., Reuben, C. R., \& Haruna, M. S. (2014). Study on the Distribution of HIV/AIDS Infections Among Age Groups Attend-ing General Hospital Toto, Central Nigeria. Int $J$ AIDS Res, 1(1), 7-10. doi: http://dx.doi.org/10.19070/2379-1586-140002

Hidayanti, E. (2013). Strategi coping stress perempuan dengan hiv/aids. Sawwa: Jurnal Studi Gender, 9(1), 89-106. doi : 10.21580/sa.v9i1.667 
Hutapea, R. (2011). AIDS \& PMS dan perkosaan. Jakarta: RT Rineka Cipta.

Kemenskes RI (2017) Profil Kesehatan Indonesia tahun 2017. https://www.kemkes.go.id/resources/download/pusdatin/profil-kesehatanindonesia/Profil-Kesehatan-Indonesia-tahun-2017.pdf

Laras, A., \& Prasetyo, A. R. (2017). Coping Terhadap Stress Kerja Pada Perawat Yang Pernah Menangani Pasien HIV/AIDS. Empati, 5(2), 353-356. https://ejournal3.undip.ac.id/index.php/empati/article/view/15216

Novianti, W., Istiyanto, B., \& Adi, T. N. (2020). Konsep Diri Penderita Hiv/Aids Di Kabupaten Kebumen, Jawa Tengah. Prosiding, 9(1). Retrieved from http://jurnal.lppm.unsoed.ac.id/ojs/index.php/Prosiding/article/view/1131

Pardede, J. A., Hutajulu, J., \& Pasaribu, P. E. (2020). Harga Diri dengan Depresi Pasien Hiv/aids. Jurnal Media Keperawatan: Politeknik Kesehatan Makassar, 11(01). https://doi.org/10.32382/jmk.v11i1.1538

Pardede, J. A., Simanjuntak, G. V., \& Waruwu, J. F. A. P. (2020). Penurunan Tingkat Kecemasan Pasien HIV/AIDS melalui Terapi Hipnotis Lima Jari. Coping: Community of Publishing in Nursing, 8, 85-90. Available at: https://ocs.unud.ac.id/index.php/coping/article/view/59612. Date accessed: 02 dec. 2020.

Riskesdas (2018). Hasil Utama Riset kesehatan Dasar 2018: Kementerian Kesehatan Badan Penelitian dan Pengembangan Kesehatan. https://www.kemkes.go.id/resources/download/info-terkini/hasil riskesdas2018.pdf

Rusmawati, A. (2012). Persepsi konsep diri orang dengan HIV/AIDS (ODHA) dalam kelompok dukungan sebaya (KDS) di kota dan kabupaten Kediri. STRADA Jurnal Ilmiah Kesehatan, 1(1), 63-70. Retrieved from https://sjik.org/index.php/sjik/article/view/23

Sari, Y. K., \& Wardani, I. Y. (2017). Dukungan Sosial dan Tingkat Stres Orang Dengan HIV/AIDS. Jurnal Keperawatan Indonesia, 20(2), 85-93. https://doi.org/10.7454/jki.v20i2.361

Sarikusuma, H., \& Hasanah, N. (2012). Self-concept of people with HIV and AIDS (ODHA) who experience negative labelling and discrimination from their social environment. Psikologia: Journal Pemikirian dan Penelitian Psikologi, 7(1), 2940. https://doi.org/10.32734/psikologia.v7i1.2533

Stuart, G. W. (2014). Principles and practice of psychiatric nursing-e-book. Elsevier Health Sciences.

UNAIDS. DATA (2017). Joint United Nations Programme on HIV/AIDS. https://www.unaids.org/sites/default/files/media_asset/2017_data-book_en.pdf

Wahyu, S., Taufik, T., \& Ilyas, A. (2012). Konsep Diri dan Masalah yang Dialami Orang Terinfeksi HIV/AIDS. Konselor, 1(2). https://doi.org/10.24036/0201212695$0-00$

World Health organization. (2020). HIV/AIDS. Available from https://www.who.int/news-room/fact-sheets/detail/hiv-aids 